\title{
Investigation of Gain Enhancement in Microstrip Antenna Structure in Pathological Tissue Samples
}

\author{
Rabia Toprak $^{1 *}$, Seyfettin Sinan Gültekin ${ }^{2}$, Dilek Uzer ${ }^{2}$

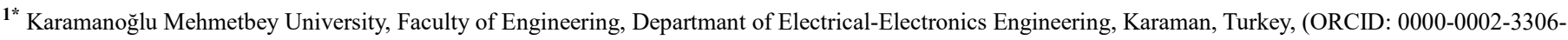 \\ 1163), rabiatop@kmu.edu.tr \\ ${ }^{2}$ Konya Technical University, Faculty of Engineering and Nature Sciences, Departmant of Electrical-Electronics Engineering, Konya, Turkey, (ORCID: 0000-0002- \\ 6287-9124, 0000-0003-3850-3810), ssgultekin@ktun.edu.tr, duzer@ktun.edu.tr
}

(1st International Conference on Applied Engineering and Natural Sciences ICAENS 2021, November 1-3, 2021)

(DOI: $10.31590 /$ ejosat.1017064)

ATIF/REFERENCE: Toprak, R., Gültekin, S. S. \& Uzer, D. (2021). Investigation of Gain Enhancement in Microstrip Antenna Structure in Pathological Tissue Samples. European Journal of Science and Technology, (28), 1360-1365.

\begin{abstract}
Pathological reports play an important role in the diagnosis and especially in the treatment of diseases. For this reason, it is important to be able to access the reports of pathological tissue samples in a short time. Today, depending on the pathologist and the number of samples, the report delivery time can take months. For this reason, microstrip antenna structures, which are frequently used in the biomedical field, are investigated to evaluate pathological tissue samples. In this study, the variation of the gain values of antenna structures depending on the simulation results is examined. FR-4 substrate material, which has a dielectric constant of 4.4, is used in the microstrip antenna structure. The diameters of four circles added to the antenna patch structure with an operating frequency of 2.45 $\mathrm{GHz}$ are changed parametrically. The highest gain value of the antenna structure is investigated. The gain value has been increased from $1.89 \mathrm{~dB}$ to about $3.5 \mathrm{~dB}$.
\end{abstract}

Keywords: Pathology, Microstrip, Patch, Gain, HFSS.

\section{Patolojik Doku Örneklerinde Mikroşerit Anten Yapısında Kazanç Artırımının İncelenmesi}

$\ddot{O} z$

Patolojik raporlar hastalıkların teşhis ve özellikle tedavisinde önemli rol oynamaktadır. Bu sebeple patolojik doku örneklerine ait raporlara kısa sürede erişim sağlayabilmek önem arz etmektedir. Günümüzde patolog ve numune sayısına bağlı olarak değişen rapor ulaşım süresi ayları bulabilmektedir. Bu sebeple, biyomedikal alanda sıklıkla kullanılan mikroşerit anten yapıları patolojik doku örneklerine ait değerlendirmeleri yapmada araştırılmaktadır. Bu çalışmada anten yapılarına ait kazanç değerlerinin simülasyon sonuçlarına bağlı olarak değişimi incelenmiştir. Mikroşerit anten yapısında 4.4 delektrik sabiti değerine sahip olan FR-4 malzemesi kullanılmıştır. $2.45 \mathrm{GHz}$ çalışma frekansı olan anten yapısına eklenen dört adet dairenin çapları parametrik olarak değiştirilmiştir. Anten yapısının en yüksek kazanç değeri araştırılmıştır. Kazanç değeri 1.89 dB'den yaklaşık 3.5 dB değerine yükseltilmiştir.

Anahtar Kelimeler: Patoloji, Mikroşerit, Yama, Kazanç, HFSS.

\footnotetext{
${ }^{*}$ Corresponding Author: rabiatop@,kmu.edu.tr
} 


\section{Introduction}

Pathology is the science of the causes and effects of diseases, especially the branch of medicine that deals with the laboratory examination of samples of body tissue for diagnostic or forensic purposes (Kamel, 2011; Nakhleh, 2006). Pathologists prepare the pathological report results. These results can take months to prepare and reach the patient and the doctor. These periods can sometimes be long for the diagnosis to be made and the treatment to be applied to the patient.

In medical applications, antenna structures are among the growing trends (Baek, Kim, Park, Jeong, \& Kim, 2018; Catherwood \& Mclaughlin, 2018; Darwish \& Hassanien, 2011; R. Das \& Yoo, 2018; Garcia-pardo et al., 2018; Ozturk \& Güneşer, 2019; Ren, Qing, Zhao, Wang, \& Gao, 2018; Schwartz, n.d.; Sun, Muneer, Li, \& Zhu, 2018). Especially microstrip patch antenna structures use often in biomedical solutions (Hasan, Shanto, Howlader, \& Jahan, 2018; Khan, Razzaq, Iqbal, Qamar, \& Zubair, 2018; Li, Guo, Zhang, \& Du, 2017; Nesasudha \& Fairy, 2018; Sabban, 2013; Top, 2017; Z. J. Yang \& Xiao, 2018a). Small dimension, weight, cost and variations of patch structure are some advantages of them. Also ease of use and variations of dielectric substrate materials are other advantages. Low efficiency, low gain and low impedance capability are some disadvantages.

Microstrip patch antennas used in biomedical area need to carry some properties. One of these properties is 'antenna gain'. In the literature, there are studies to increase antenna gain. In addition, these studies contain several methods to do this. Some methods of it are adding shorting pins in the antenna structure, adding different slot types and making changes on ground layer (Cao et al., 2019; Chen et al., 2020; Feng, Sun, \& Leung, 2016; Lesnik, Verhovski, Mizrachi, Milgrom, \& Haridim, 2018; Mustacchio, Boccia, Arnieri, \& Amendola, 2021; Q. Yang et al., 2011).

In this paper, gain enhancement study of a microstrip antenna operating in the $2.45 \mathrm{GHz}$ radiation region has been carried out. The process of it actualizes by changing the patch area of the antenna structure (S. Das \& Mitra, 2018; Feng et al., 2016). The antenna with increased gain has been tested on pathological tissue samples with normal and tumorous skin tissue. To increase the antenna gain, microstrip patch dimensions are modified. To simulate the antenna and system design, ANSYS HFSS is used.

Section 2 explains material and method of the study. Results and Discussion is in Section 3. Finally, Conclusions and Recommendations are in Section 4.

\section{Material and Method}

\subsection{Antenna Structure}

Antenna operating frequency is selected $2.45 \mathrm{GHz}$ because of ISM (Industrial, Scientific and Medical) bands. As substrate material is used FR-4 that has 4.4 dielectric constant value. Antenna dimensions are obtained from Equations 2.1 and 2.2 (B. J. Kwaha, O. N. Inyang, 2011). For finding the resonance frequency, lots of simulations are implemented. After simulations, substrate dimension is found $38.3 \times 38.3 \times 1.575 \mathrm{~mm}^{3}$. Proposed antenna patch structure is obtained by combining a concentric circle with a diameter of $28.84 \mathrm{~mm}$ and 4 concentric circles with a diameter of $16 \mathrm{~mm}$ at the same distance from the center. Figure 1 shows the antenna structure.

e-ISSN: 2148-2683

$$
\begin{aligned}
& a=\frac{F}{\left\{1+\frac{2 h}{\pi \varepsilon_{r} F}\left[\ln \left(\frac{\pi F}{2 h}\right)+1.7726\right]\right\}^{\frac{1}{2}}} \\
& F=\frac{8.971 \times 10^{9}}{f_{r} \sqrt{\varepsilon_{r}}}
\end{aligned}
$$

Where, $a$ is radius of the circular patch, $f_{r}$ is resonance frequency, $\varepsilon_{r}$ is dielectric constant of substrate and $h$ is height of substrate.

Return loss of the proposed antenna is showed in Figure 2.

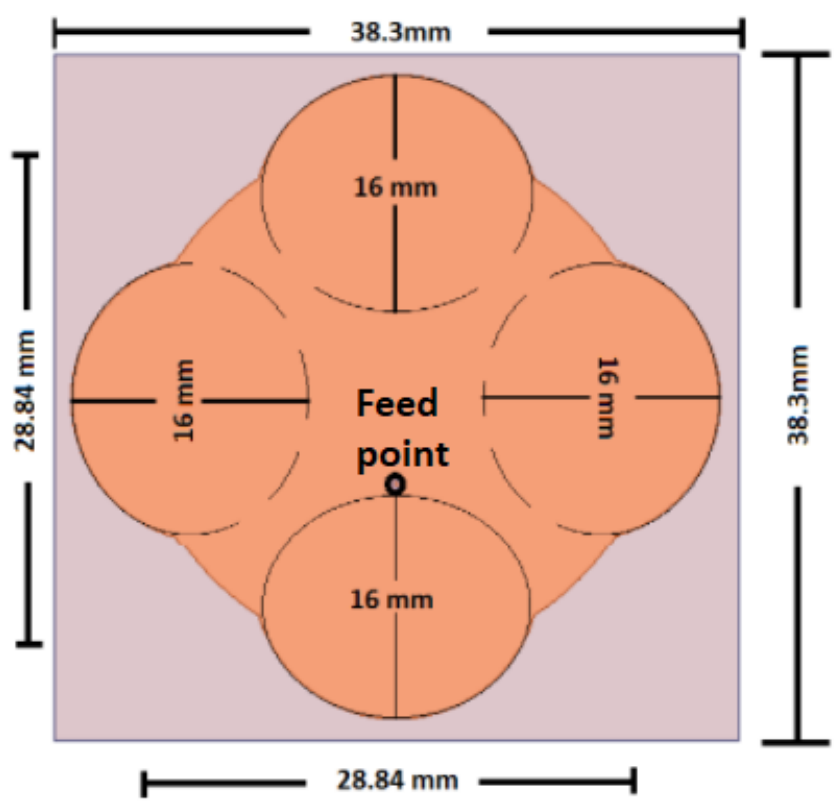

Figure 1. Proposed antenna structure and its dimensions

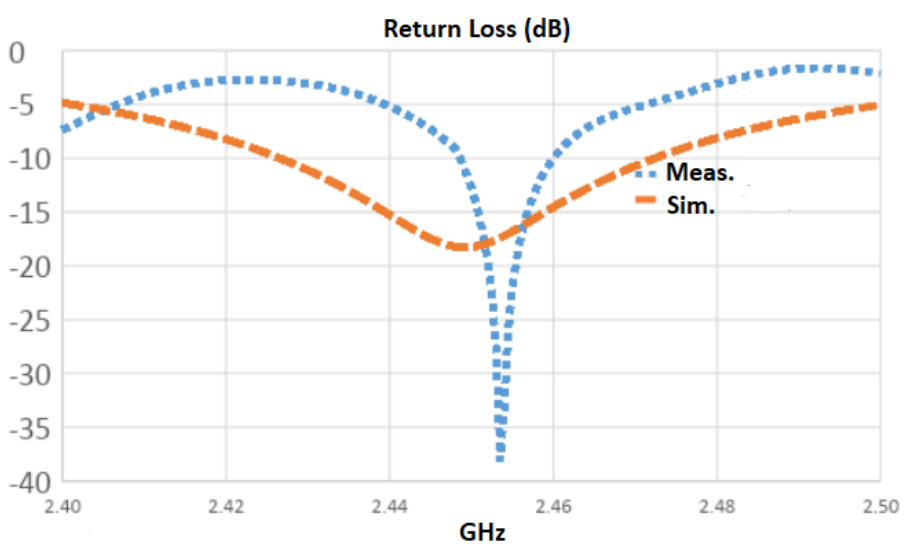

Figure 2. Return Loss of the antenna structure

\subsection{Gain Enhancement}

In microstrip patch antenna applications, there are several methods to increase antenna gain. Antenna gain depends on directivity and efficiency of the antenna structure (Equation 2.3) (Balanis, 2013). Where, $G$ is gain, $\eta$ is the efficiency and $D$ is directivity of antenna structure.

$$
G=\eta D
$$

Patch dimension is modified to increase the proposed antenna gain. In the literature, there are many studies about this subject. If explained in detail, the gain of any antenna structure depends on its effective radiating area, $A_{\text {eff. }}$. Gain value can be expressed with an identical reference antenna in Equations 2.4 and 2.5 (Guha, Chattopadhya, \& Siddiqu, 2010). 


$$
\begin{aligned}
& \Delta G[d B]=10 \log \left[\frac{\left(\frac{A_{e f f}}{\lambda_{0}^{2}}\right)_{\text {air }}}{\left(\frac{A_{e f f}}{\lambda_{0}^{2}}\right)_{r e f}}\right] \\
& A_{e f f}=(L+2 \Delta L)(W+2 \Delta W)
\end{aligned}
$$

Where $\lambda_{0}$ is the operating wavelength of the signal, $L$ and $W$ are the length and width of the patch, respectively.

So, patch dimensions of the antenna are important parameters on antenna gain values. In this study, by changing patch dimensions, it is aimed to increase the gain of antenna structure. Figure 3 shows the phsysical changes on antenna patch. By adding 4 same circles as showed in the Figure 3, the parametric analysis is done in HFSS. The circle radius is from $1.5 \mathrm{~mm}$ to $9.5 \mathrm{~mm}$ by changing $0.5 \mathrm{~mm}$ step.

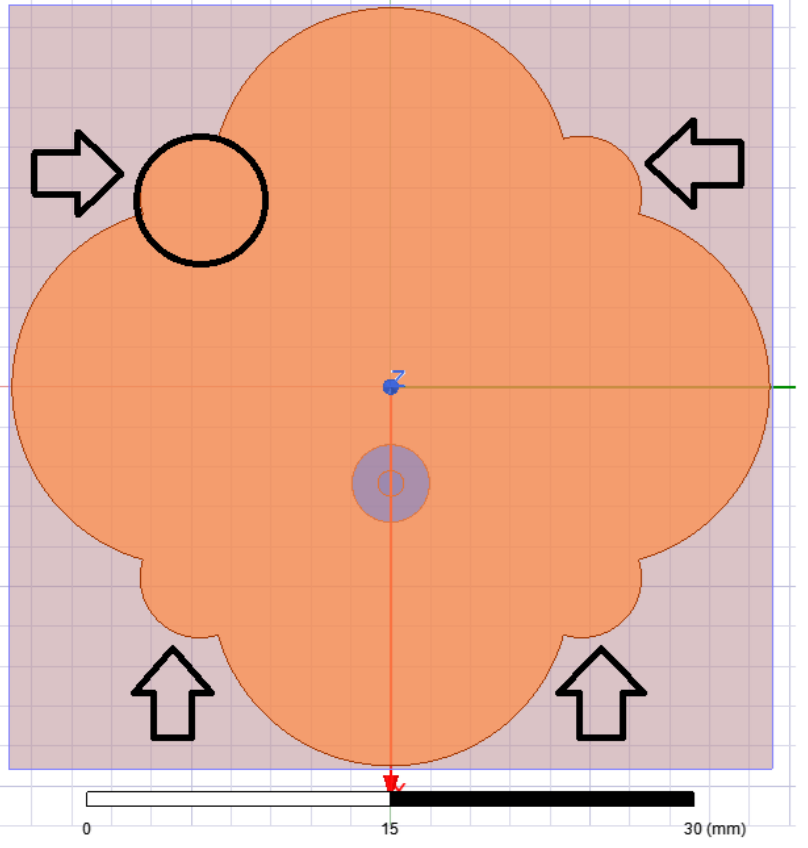

\subsection{Modeled System}

Pathological tissue samples are modeled as showed in Figure 4. Normal and tumorous skin tissues are introduced in HFSS program. Any body part has different electrical properties like any material. So, normal and tumorous skin tissue have different dielectric constant values. These values are obtained in (Gabriel, 1996). Normal and tumorous skin tissue has the dielectric constant of 38 and 50, respectively. Thus, the modeled system is shown in Figure 4. For simulations, two identical antenna structures are used in the system.

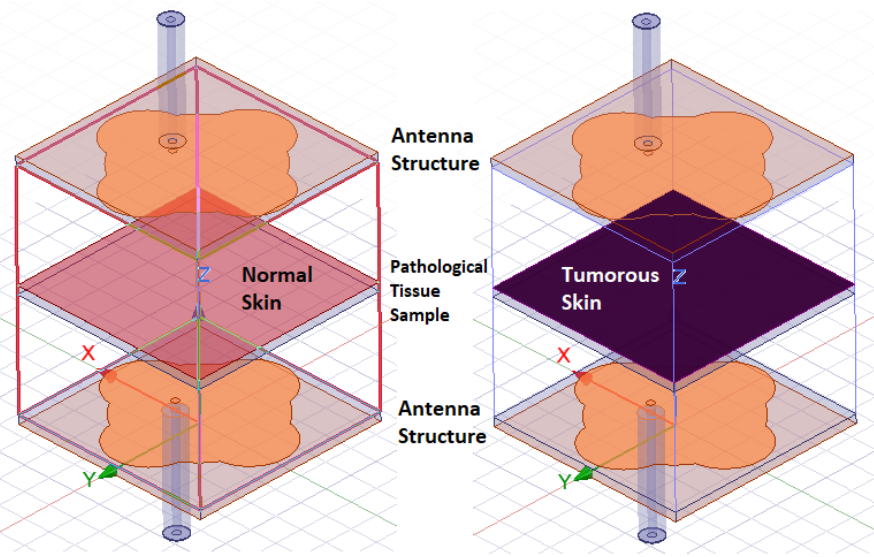

Figure 4. Modeled system

Also, between two antenna structures, there are pathological tissue samples. In the centre there is a glass slide that fixed skin tissue samples. These samples are spread on the glass to cover the entire slide. Height of samples is $5 \mu \mathrm{m}$. Normally patological tissues' heights changes from $2 \mu \mathrm{m}$ to $5 \mu \mathrm{m}$.

\section{Results and Discussion}

The maximum gain of the antenna structure in Figure 1 is obtained as $1.89 \mathrm{~dB}$ from HFSS (Figure 5).

Figure 3. Changes on the patch of the antenna structure

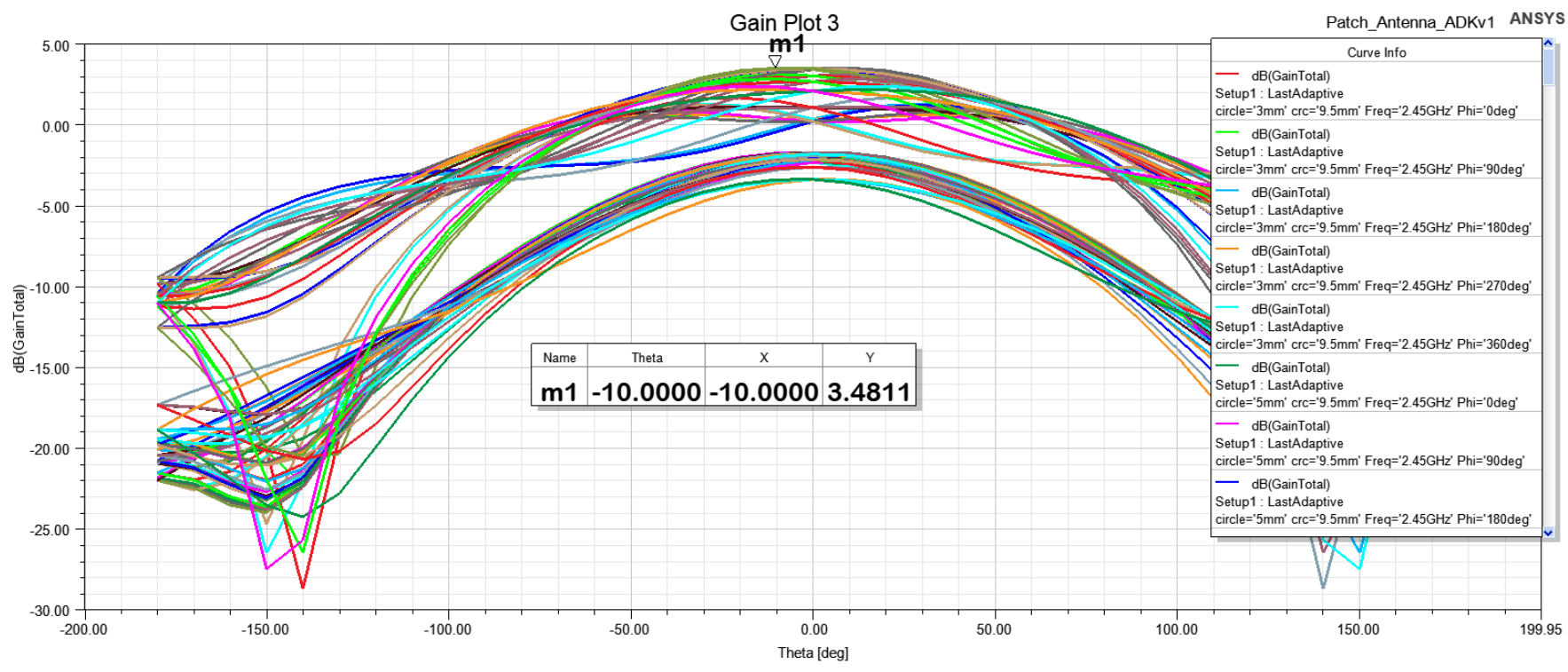

Figure 6. Gain values in $d B$ after parametric analyzes 


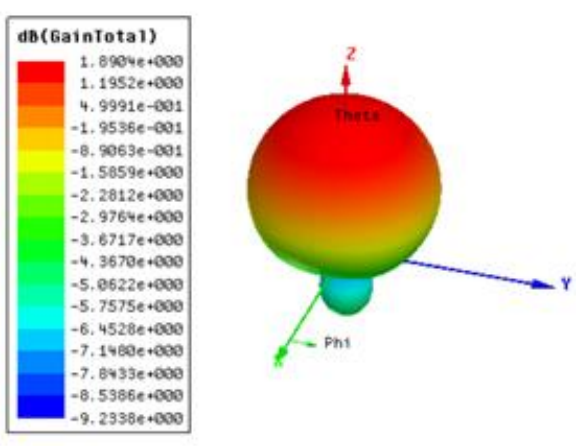

Figure 5. The gain of the antenna in Figure 1

Table 1. The comparition of gain values with reference antennas

\begin{tabular}{l|c|c}
\hline References & $\begin{array}{c}\text { Dimensions } \\
\mathbf{( m m}^{\mathbf{3}} \mathbf{)}\end{array}$ & $\begin{array}{c}\text { Gain } \\
\mathbf{( d B i )}\end{array}$ \\
\hline (Z. J. Yang \& Xiao, 2018b) & 80 & -20.80 \\
\hline (Li et al., 2017) & 120.69 & -22.70 \\
\hline (Nikolayev et al., 2019) & 695 & -15 \\
\hline (Marnat, Ouda, Arsalan, Salama, \& & - & -16 \\
Shamim, 2012) & - & -29 \\
\hline (Liu, Guo, \& Xiao, 2012) & - & -19.90 \\
\hline (Schmidt et al., 2014) & 2310.3 & 1.89 \\
\hline Proposed normal antenna & 2310.3 & 3.48 \\
\hline Proposed gain antenna & & \\
\hline
\end{tabular}

When analyzes are applied to mention above, the expression of the gain in $\mathrm{dB}$ is shown in Figure 6. According to theta angle, while phi angle is changing from 0 degree to 360 degree by 90 degree, gain plot in $\mathrm{dB}$ is shown. Maximum gain value is about $3.5 \mathrm{~dB}$ in theta $=-10^{\circ}$ and $\mathrm{phi}=-90^{\circ}$, when the radii of the circles are $7 \mathrm{~mm}$. The comparition of gain values with the proposed gain antenna and reference antenna structures is in Table 1. Reference antennas are selected to be able to compare as microstrip antennas.

Table 2. The variation of S-parameters with respect to their arithmetic mean

\begin{tabular}{l|c|c|c|c}
\hline S-parameters & $\mathbf{S}_{\mathbf{1 1}}$ & $\mathbf{S}_{\mathbf{2 1}}$ & $\mathbf{S}_{\mathbf{1 2}}$ & $\mathbf{S}_{\mathbf{2 2}}$ \\
\hline $\begin{array}{l}\text { Skin value of proposed } \\
\text { antenna }\end{array}$ & 0.92 & 32.29 & 32.20 & 0.92 \\
\hline \begin{tabular}{l} 
Skin value of gain antenna \\
\hline $\begin{array}{l}\text { Tumorous value of } \\
\text { Proposed antenna }\end{array}$
\end{tabular} & 0.70 & 33.05 & 32.97 & 0.70 \\
\hline $\begin{array}{l}\text { Tumorous value of gained } \\
\text { antenna }\end{array}$ & 0.72 & 34.02 & 34.00 & 0.72 \\
\hline $\begin{array}{l}\text { Percentage change for } \\
\text { gain antenna in skin tissue }\end{array}$ & 75.70 & 102.33 & 102.14 & 75.40 \\
$\begin{array}{l}\text { Percentage change for } \\
\text { gain antenna in tumorous } \\
\text { tissue }\end{array}$ & 77.31 & 104.90 & 104.93 & 77.12 \\
\hline
\end{tabular}

e-ISSN: $2148-2683$
Also, Table 2 explains the variation of S-parameters with respect to their arithmetic mean. That is obtained by taking absolute values for every $S$-parameter value, $S_{11}, S_{21}, S_{12}$ and $S_{22}$. Especially in the antenna applications, these values are important because of giving the radiation information of antenna structure (Caspers, 2011).

When Table 2 is examined, it is reached a different value for each S-parameter. These values matter the success of the gain antenna. While the differences for $S_{11}$ and $S_{22}$ values are 0.01 for a normal antenna, this difference is 0.02 for a gain antenna. For $\mathrm{S}_{21}$ and $\mathrm{S}_{12}$, these values are 0.12 and 0.20 for normal antenna, and 0.97 and 1.03 for gain antenna, respectively. When the values of the gain antenna are compared with the values of the normal antenna, it is seen that the differences of the gain antenna are higher.

When the values obtained from the normal antenna are compared for the values obtained from the gain antenna, the percentage of differences for each tissue is shown in the Table 2. As handling the skin tissue, the percentage of difference is about $25 \%$ for $S_{11}$ and $S_{22}$. It is about $2.5 \%$ for $S_{21}$ and $S_{12}$. As handling the tumorous skin tissue, the percentage of difference is about $23 \%$ for $S_{11}$ and $S_{22}$. It is about $5 \%$ for $S_{21}$ and $S_{12}$.

\section{Conclusions and Recommendation}

Access to pathological results reports can take months. It is important to access these reports, which are important for the patient and the doctor, in a short time. because it directs the diagnosis and treatment of the patient and the disease. For this purpose, antenna structures that are frequently used in the literature are investigated. One of them is microstrip antenna structures due to its various advantages.

Microstrip patch antennas have low gain. Studies are being done to increase the gain of antenna structure in this area. Some of these studies can be listed as adding a short-circuit pin, modifying the ground layer and opening different slots on the patch.

In this study, it is aimed to increase the gain by changing the pre-designed microstrip patch antenna dimensions. Parametric analysis was carried out with the 4 equal circle structure added to the patch part. As a result of the analysis, the antenna gain increased from $1.89 \mathrm{~dB}$ to $3.48 \mathrm{~dB}$ with circles with a radius of 7 $\mathrm{mm}$. With this gain antenna, simulations of pathological normal and tumorous skin tissue were made. To do this, a system is modelled that mentioned above. The absolute values of the obtained S-parameters were taken and their arithmetic averages were checked. When the data of the obtained S-parameters are examined, it is shown that the gain antenna reaches a higher difference for each S-parameter value.

For example, for skin tissue, $\mathrm{S}_{11}$ arithmetic mean value is 0.92 of proposed antenna and 0.70 of gain antenna. If the difference is examined as a percentage, it is seen that there is a difference of approximately $25 \%$. Or $\mathrm{S}_{12}$ arithmetic value is 32.20 of proposed antenna and 32.97 of gain antenna. There is a difference of $2.3 \%$ for skin tissue. When the differences and percentages are examined, it is possible to say that the use of the gain antenna structure in pathological tissue samples will be beneficial.

Designing microstrip antennas with different gain values with a modeled system will increase the quality and quantity of the study. 


\section{Acknowledge}

This study is supported by Konya Technical University Scientific Research Projects Coordinatorship with project number 211102032.

\section{References}

B. J. Kwaha, O. N. Inyang, P. A. (2011). The circular microstrip patch antenna-design and implementation. International Journal of Recent Research and Applied Studies (IJRRAS), $8(1), 86-95$.

Baek, J. J., Kim, S. W., Park, K. H., Jeong, M. J., \& Kim, Y. T. (2018). Design and performance evaluation of $13.56-\mathrm{MHz}$ passive RFID for E-skin sensor application. IEEE Microwave and Wireless Components Letters, 28(12), 1074-1076. https://doi.org/10.1109/LMWC.2018.2876764

Balanis, C. A. (2013). Anten teorisi : analiz ve tasartm. Nobel Akademik Yayıncılık.

Cao, Y., Cai, Y., Cao, W., Xi, B., Qian, Z., Wu, T., \& Zhu, L. (2019). Broadband and High-Gain Microstrip Patch Antenna Loaded With Parasitic Mushroom-Type Structure. IEEE Antennas and Wireless Propagation Letters, 18(7), 1405-1409. https://doi.org/10.1109/LAWP.2019.2917909

Caspers, F. (2011). RF engineering basic concepts: S-parameters. CAS 2010 - CERN Accelerator School: RF for Accelerators, Proceedings, (June), 67-93.

Catherwood, P. A., \& Mclaughlin, J. (2018). Internet of ThingsEnabled Hospital Wards. (June), 10-18.

Chen, Y., Wang, S., Shi, S., Ding, J., Jiang, M., Wang, T., \& Zhai, G. (2020). Gain Enhancement for Landstorfer Yagi Antenna Using Zero- Index Metamaterials. 2020 IEEE MTT-S International Wireless Symposium, IWS 2020 Proceedings. https://doi.org/10.1109/IWS49314.2020.9359970

Darwish, A., \& Hassanien, A. E. (2011). Wearable and implantable wireless sensor network solutions for healthcare monitoring. Sensors, 11(6), 5561-5595. https://doi.org/10.3390/s110605561

Das, R., \& Yoo, H. (2018). Application of a Compact Electromagnetic Bandgap Array in a Phone Case for Suppression of Mobile Phone Radiation Exposure. IEEE Transactions on Microwave Theory and Techniques, 66(5), 2363-2372. https://doi.org/10.1109/TMTT.2017.2786287

Das, S., \& Mitra, D. (2018). A compact wideband flexible implantable slot antenna design with enhanced gain. IEEE Transactions on Antennas and Propagation, 66(8), 43094314. https://doi.org/10.1109/TAP.2018.2836463

Feng, L. Y., Sun, Y., \& Leung, K. W. (2016). Gain enhanced omnidirectional cylindrical ring dielectric resonator antenna. 2016 IEEE Antennas and Propagation Society International Symposium, APSURSI 2016 - Proceedings, 139-140. https://doi.org/10.1109/APS.2016.7695778

Gabriel, C. (1996). Compilation of the Dielectric Properties of Body Tissues at RF and Microwave Frequencies. Environmental Health, Report No.(June), 21. https://doi.org/Report N.AL/OE-TR- 1996-0037

Garcia-pardo, C., Andreu, C., Fornes-leal, A., Castelló-palacios, S., Perez-simbor, S., \& Barbi, M. (2018). Ultrawideband Technology for Medical In-Body Sensor Networks. (june), 19-33. https://doi.org/10.1109/MAP.2018.2818458

Guha, D., Chattopadhya, S., \& Siddiqu, J. Y. (2010). Estimation of gain enhancement replacing PTFE by air substrate in a microstrip patch antenna. IEEE Antennas and Propagation Magazine, 52(3), 92-95. https://doi.org/10.1109/MAP.2010.5586581

Hasan, R. R., Shanto, M. A. H., Howlader, S., \& Jahan, S. (2018). A novel design and miniaturization of a scalp implantable circular patch antenna at ISM band for biomedical application. 2017 Intelligent Systems Conference, IntelliSys 2017, 2018-Janua(September), 166-169. https://doi.org/10.1109/IntelliSys.2017.8324286

Kamel, H. M. (2011). Trends and Challenges in Pathology Practice Choices and necessities. 11(1), 38-44.

Khan, Z., Razzaq, A., Iqbal, J., Qamar, A., \& Zubair, M. (2018). Double circular ring compact antenna for ultra-wideband applications. IET Microwaves, Antennas and Propagation, 12(13), 2094-2097. https://doi.org/10.1049/ietmap.2018.5245

Lesnik, R., Verhovski, N., Mizrachi, I., Milgrom, B., \& Haridim, M. (2018). Gain enhancement of a compact implantable dipole for biomedical applications. IEEE Antennas and Wireless Propagation Letters, 17(10), 1778-1782. https://doi.org/10.1109/LAWP.2018.2866233

Li, R., Guo, Y. X., Zhang, B., \& Du, G. (2017). A Miniaturized Circularly Polarized Implantable Annular-Ring Antenna. IEEE Antennas and Wireless Propagation Letters, 16, 2566-2569. https://doi.org/10.1109/LAWP.2017.2734246

Liu, C., Guo, Y. X., \& Xiao, S. (2012). Compact dual-band antenna for implantable devices. IEEE Antennas and Wireless Propagation Letters, 11, 1508-1511. https://doi.org/10.1109/LAWP.2012.2233705

Marnat, L., Ouda, M. H., Arsalan, M., Salama, K., \& Shamim, A. (2012). On-chip implantable antennas for wireless power and data transfer in a glaucoma-monitoring SoC. IEEE Antennas and Wireless Propagation Letters, 11, 1671-1674. https://doi.org/10.1109/LAWP.2013.2240253

Mustacchio, C., Boccia, L., Arnieri, E., \& Amendola, G. (2021). Gain Enhancement Technique for On-Chip Monopole Antenna. 2020 50th European Microwave Conference, EuMC 2020, 650-653. https://doi.org/10.23919/EUMC48046.2021.9338160

Nakhleh, R. E. (2006, July 1). What is quality in surgical pathology? Journal of Clinical Pathology, Vol. 59, pp. 669672. https://doi.org/10.1136/jcp.2005.031385

Nesasudha, M., \& Fairy, J. J. (2018). Low profile antenna design for biomedical applications. Proceedings of IEEE International Conference on Signal Processing and Communication, ICSPC 2017, 2018-Janua(July), 139-142. https://doi.org/10.1109/CSPC.2017.8305825

Nikolayev, D., Joseph, W., Skrivervik, A., Zhadobov, M., Martens, L., \& Sauleau, R. (2019). Dielectric-Loaded Conformal Microstrip Antennas for Versatile In-Body Applications. IEEE Antennas and Wireless Propagation Letters, 18(12), 2686-2690. https://doi.org/10.1109/LAWP.2019.2948814

Ozturk, T., \& Güneşer, M. T. (2019). Measurement Methods and Extraction Techniques to Obtain the Dielectric Properties of Materials. In Electrical and Electronic Properties of Materials (pp. 1-27). https://doi.org/10.5772/intechopen.80276

Ren, A., Qing, M., Zhao, N. A. N., Wang, M., \& Gao, G. E. (2018). Nano-Ferrite Near-Field Microwave Imaging for In-Body Applications. 6, 29551-29557.

Sabban, A. (2013). New wideband printed antennas for medical applications. IEEE Transactions on Antennas and 
Propagation, 61(1), 84-91. https://doi.org/10.1109/TAP.2012.2214993

Schmidt, C., Casado, F., Arriola, A., Ortego, I., Bradley, P. D., \& Valderas, D. (2014). Broadband UHF implanted 3-D conformal antenna design and characterization for in-off body wireless links. IEEE Transactions on Antennas and Propagation, 62(3), 1433-1444. https://doi.org/10.1109/TAP.2013.2295816

Schwartz, R. (n.d.). Measurement of Dielectric Material Properties Application Note Products.

Sun, G., Muneer, B., Li, Y., \& Zhu, Q. (2018). Ultracompact Implantable Design with Integrated Wireless Power Transfer and RF Transmission Capabilities. IEEE Transactions on Biomedical Circuits and Systems, 12(2), 281-291. https://doi.org/10.1109/TBCAS.2017.2787649

Top, R. (2017). A transmitter microstrip antenna design and application towards the detection of heart disease parameters. Selcuk University.

Yang, Q., Zhang, X., Wang, N., Bai, X., Li, J., \& Zhao, X. (2011). Cavity-backed circularly polarized self-phased four-loop antenna for gain enhancement. IEEE Transactions on Antennas and Propagation, 59(2), 685-688. https://doi.org/10.1109/TAP.2010.2096395

Yang, Z. J., \& Xiao, S. (2018a). A wideband implantable antenna for $2.4 \mathrm{GHz}$ ISM band biomedical application. 2018 IEEE International Workshop on Antenna Technology, IWAT2018 - Proceedings, 1-3. https://doi.org/10.1109/IWAT.2018.8379168

Yang, Z. J., \& Xiao, S. (2018b). A wideband implantable antenna for $2.4 \mathrm{GHz}$ ISM band biomedical application. 2018 IEEE International Workshop on Antenna Technology, IWAT2018 - $\quad$ Proceedings, 1-3. https://doi.org/10.1109/IWAT.2018.8379168 